\title{
Electrochemical Deposition of Platinum and Palladium on Gold Nanoparticles Loaded Carbon Nanotube Support for Oxidation Reactions in Fuel Cell
}

\author{
Surin Saipanya, ${ }^{1,2}$ Somchai Lapanantnoppakhun, ${ }^{1,3}$ and Thapanee Sarakonsri ${ }^{1,2}$ \\ ${ }^{1}$ Department of Chemistry, Faculty of Science, Chiang Mai University, Chiang Mai 50200, Thailand \\ ${ }^{2}$ Materials Science Research Center, Faculty of Science, Chiang Mai University, Chiang Mai 50200, Thailand \\ ${ }^{3}$ Center of Excellence for Innovation in Analytical Science and Technology, Chiang Mai University, Chiang Mai 50200, Thailand
}

Correspondence should be addressed to Surin Saipanya; surin_saipanya@hotmail.co.uk

Received 20 March 2014; Revised 30 May 2014; Accepted 12 June 2014; Published 26 June 2014

Academic Editor: Jae Ryang Hahn

Copyright (C) 2014 Surin Saipanya et al. This is an open access article distributed under the Creative Commons Attribution License, which permits unrestricted use, distribution, and reproduction in any medium, provided the original work is properly cited.

Pt and Pd sequentially electrodeposited Au nanoparticles loaded carbon nanotube (Au-CNT) was prepared for the electrocatalytic study of methanol, ethanol, and formic acid oxidations. All electrochemical measurements were carried out in a three-electrode cell. A platinum wire and $\mathrm{Ag} / \mathrm{AgCl}$ were used as auxiliary and reference electrodes, respectively. Suspension of the Au-CNT, phosphate buffer, isopropanol, and Nafion was mixed and dropped on glassy carbon as a working electrode. By sequential deposition method, $\mathrm{PdPtPt} / \mathrm{Au}-\mathrm{CNT}$, PtPdPd/Au-CNT, and PtPdPt/Au-CNT catalysts were prepared. Cyclic voltammograms (CVs) of those catalysts in $1 \mathrm{M} \mathrm{H}_{2} \mathrm{SO}_{4}$ solution showed hydrogen adsorption and hydrogen desorption reactions. $\mathrm{CV}$ responses for those three catalysts in methanol, ethanol, and formic acid electrooxidations studied in $2 \mathrm{M} \mathrm{CH}_{3} \mathrm{OH}, \mathrm{CH}_{3} \mathrm{CH}_{2} \mathrm{OH}$, and $\mathrm{HCOOH}$ in $1 \mathrm{M} \mathrm{H}_{2} \mathrm{SO}_{4}$ show characteristic oxidation peaks. The oxidation peaks at anodic scan contribute to those organic substance oxidations while the peaks at cathodic scan are related with the reoxidation of the adsorbed carbonaceous species. Comparing all those three catalysts, it can be found that the PdPtPt/Au-CNT catalyst is good at methanol oxidation; the PtPdPt/Au-CNT effectively enhances ethanol oxidation while the PtPdPd/Au-CNT exceptionally catalyzes formic acid oxidation. Therefore, a different stoichiometry affects the electrochemical active surface area of the catalysts to achieve the catalytic oxidation reactions.

\section{Introduction}

Lack of power supply with high future consuming is the problem that everyone knows that they are going to face. Fuel cells are recognized because achievement of an electric energy can directly produce from the reaction of chemical substances [1-3]. Proton exchange fuel cell (PEMFC) is a leading candidate for nowadays application but it has some problems particularly hydrogen storage. However, it can be relieved by replacing hydrogen with other liquid fuels such as methanol, ethanol, and formic acid $[4,5]$. Unluckily, the slow and incomplete catalytic oxidation reactions of these organic molecules taking place at an anode are the main impediment to practical applications of the direct methanol fuel cell (DMFC), direct ethanol fuel cell (DEFC), and direct formic acid fuel cell (DFAFC) [6-8]. Pt-based materials are currently the best electrocatalysts for these reactions. Pt alloy catalysts can enhance $\mathrm{CO}$ electrooxidation kinetics $[4,5,9]$. The secondary element $(\mathrm{M})$ in the Pt-alloy catalysts can be attributed to the bifunctional mechanism and the electronic effect induced by the electronic interaction between $\mathrm{Pt}$ and $\mathrm{M}$, promoting the adsorbed $\mathrm{CO}$ intermediate oxidation at $\mathrm{Pt}$ by deteriorating the metal- $\mathrm{CO}$ bond. The catalyst can be prepared by many preparation methods such as chemical reduction, coimpregnation, solid phase reduction, ionic liquid, vapor deposition, thermal decomposition, and electrochemical deposition methods $[2,4]$. The research efforts have been dedicated to improve the Pt-based catalysts but the activity of catalysts is still insufficient. There are several serious technological challenges such as kinetic of the substances in the oxidation reactions. The oxidations have low equilibrium potentials but they need a large overpotential 
to progress which depend on catalyst and operating condition [10-15]. It is well-recognized that the structure affects the activities. The different crystallographic orientations would show different activities. Therefore, the optimization of the catalyst surface can be obtained by the high performance. Alloying Pt with a second element and incorporating active cocatalysts such as adatoms are able to achieve the goal.

Moreover, Carbon support is one of the important parts to improve the fuel cell performance to achieve high power density generation and the researchers need to consider [1618]. The high surface area of carbon with outstanding chemical and electrochemical stability, electrical conductivity, and appropriate size distribution is taken into account for metal nanoparticle catalysts to disperse on the support. With those reasons, carbon nanotube $(\mathrm{CNT})$ is one of the promising that could improve a high fuel cell performance. The CNT loaded with Au nanoparticle was used as a support in this experiment as it was expected that the Au-CNT could be a good template for the coming metal atoms (Pt or Pd) to be deposited for nucleation of catalyst nanoparticle growth [19].

In this work, electrodepositions of $\mathrm{Pt}$ and/or $\mathrm{Pd}$ at $\mathrm{Au}-$ CNT support in metal salt aqueous solutions were performed. Differential successive electrodepositions of Pt and Pd layer at $\mathrm{Au}-\mathrm{CNT}$ in electrode as a catalyst were achieved. The applications of the resulted catalysts in electrooxidations of methanol, ethanol, and formic acid are reported. Morphologies of the resulted PdPtPt/Au-CNT, PtPdPd/Au-CNT, and $\mathrm{PtPdPt} / \mathrm{Au}-\mathrm{CNT}$ catalysts were characterized by TEM. Cyclic voltammetry was used to prepare the catalysts and study their electrocatalytic properties in oxidation reactions.

\section{Materials and Methods}

2.1. Materials and Gold Nanoparticles Loaded CNT. $\mathrm{H}_{2} \mathrm{PtCl}_{6} \cdot 6 \mathrm{H}_{2} \mathrm{O}, \mathrm{PdCl}_{2}$, and $\mathrm{HAuCl}_{4}$ were obtained from Merck. Methanol, ethanol, formic acid, and sulfuric acid were received from Lab. Scan. Water was obtained from a Millipore Milli-Q water system. Gold nanoparticles were straightforwardly prepared by aqueous reduction of hydrogen tetrachloroaurate (II) with alkaline tetrakis(hydroxymethyl)phosphonium chloride [20].

2.2. Electrochemical Measurements. A glassy carbon electrode (BAS and $3.0 \mathrm{~mm}$ diameter) was polished with alumina slurries. The electrode was covered by ink paste which was prepared by mixing of Au-CNT, Nafion, phosphate buffer, and isopropanol and then dropped the mixture suspension onto the clean glassy carbon surface by micropipette and left the suspension to be dried for $30 \mathrm{~min}$. Pt and Pd salt solutions were used as a precursor for electrodeposition on $\mathrm{Au}$-CNT from the solution of $1 \mathrm{mM} \mathrm{H}_{2} \mathrm{PtCl}_{6} \cdot 6 \mathrm{H}_{2} \mathrm{O}$ and $\mathrm{PdCl}_{2}$ (dissolved in $\mathrm{HCl}$ solution). Voltammetric measurements were carried out with EDAQ potentiostat with a threeelectrode cell system. $\mathrm{Ag} / \mathrm{AgCl}$ and $\mathrm{Pt}$ wire were used as reference and counter electrodes, respectively. $\mathrm{Pt}$ and $\mathrm{Pd}$ metal sequential depositions were performed in the prepared precursor solutions. The catalysts were prepared on working electrode by cyclic voltammetry under potential between

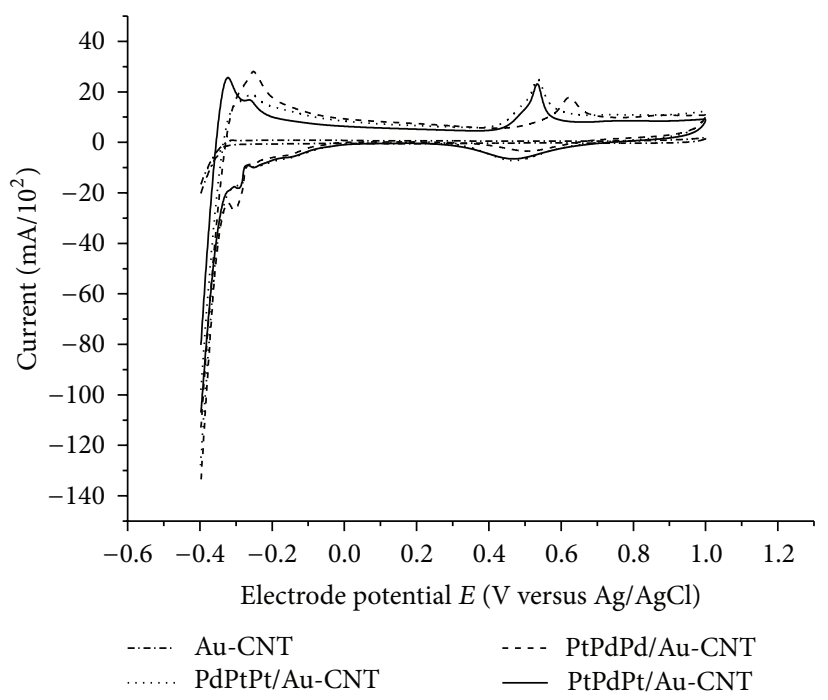

FIGURE 1: Cyclic voltammograms recorded in $1 \mathrm{M} \mathrm{H}_{2} \mathrm{SO}_{4}$ solution at $\mathrm{Au}-\mathrm{CNT}$, PdPtPt/Au-CNT, PtPdPd/Au-CNT, and PtPdPt/Au-CNT in the potential range -0.40 to $1.00 \mathrm{~V}$ at a scan rate $0.05 \mathrm{~V} \cdot \mathrm{s}^{-1}$.

-0.4 and $1.0 \mathrm{~V}$ with 3 cycles each metal solution at room temperature. The ink electrodes were used as the working electrode and the obtained catalyst electrodes were denoted as PdPtPt/Au-CNT, PtPdPd/Au-CNT, and PtPdPt/Au-CNT. The obtained catalyst electrodes were examined in $1 \mathrm{M} \mathrm{H}_{2} \mathrm{SO}_{4}$ solution and the solution of methanol, ethanol, and formic acid in $\mathrm{H}_{2} \mathrm{SO}_{4}$ solution $\left(2 \mathrm{MCH}_{3} \mathrm{OH}, \mathrm{CH}_{3} \mathrm{CH}_{2} \mathrm{OH}\right.$, and $\mathrm{HCOOH}$ in $1 \mathrm{M} \mathrm{H}_{2} \mathrm{SO}_{4}$ ) by $\mathrm{CV}$ at a scan rate of $0.05 \mathrm{~V} \cdot \mathrm{s}^{-1}$. Those solutions were bubbled by nitrogen gas for $20 \mathrm{~min}$. and kept with $\mathrm{N}_{2}$ atmosphere during the electrochemical experiments.

\section{Results and Discussion}

Three successive electrodeposited metal catalysts, PdPtPt/ $\mathrm{Au}-\mathrm{CNT}$, PtPdPd/Au-CNT, and PtPdPt/Au-CNT, were prepared for electrocatalytic activity studies. $\mathrm{CV}$ explanations for voltammic characterizations in $\mathrm{H}_{2} \mathrm{SO}_{4}$ and catalysis in methanol, ethanol, and formic acid oxidations are stated. Figure 1 shows general shape of CVs for $\mathrm{Au}-\mathrm{CNT}$, PdPtPt/AuCNT, PtPdPd/Au-CNT, and PtPdPt/Au-CNT in $1 \mathrm{M} \mathrm{H}_{2} \mathrm{SO}_{4}$ solution at scan rate $0.05 \mathrm{~V} \cdot \mathrm{s}^{-1}$ in a potential window of -0.40 to $1.00 \mathrm{~V}$ versus $\mathrm{Ag} / \mathrm{AgCl}$. The Au-CNT electrode shows no hydrogen adsorption/desorption peak. For PdPtPt/AuCNT, PtPdPd/Au-CNT, and PtPdPt/Au-CNT electrodes, the hydrogen adsorption/desorption peaks are defined. Hydrogen adsorption/desorption peaks for the catalysts are not totally sharp indicating that some $\mathrm{Pt}$ are blocked on the surface by Pd oxide. The potential region of the hydrogen adsorption/desorption $(-0.10-0.30 \mathrm{~V})$ is separated from the reversible/irreversible oxide by the double layer potential region. The double layer for those catalysts is rather similar attributed to similar metal loading amount [21, 22]. Hydrogen desorption peaks of PdPtPt/Au-CNT, PtPdPd/Au-CNT, and $\mathrm{PtPdPt} / \mathrm{Au}-\mathrm{CNT}$ are ca. $-0.23,-0.25$, and $-0.35 \mathrm{~V}$ while 
TABLE 1: Onset potentials and oxidation current intensities of PdPtPt/Au-CNT, PtPdPd/Au-CNT, and PtPdPt/Au-CNT in the potential range from 0.00 to $1.00 \mathrm{~V}$ at a scan rate $0.05 \mathrm{~V} \cdot \mathrm{s}^{-1}$.

\begin{tabular}{lcccccc}
\hline & \multicolumn{2}{c}{ Methanol oxidation } & \multicolumn{2}{c}{ Ethanol oxidation } & \multicolumn{2}{c}{ Formic acid oxidation } \\
Prepared catalyst & $\begin{array}{c}\text { Onset potential } \\
(\mathrm{V})\end{array}$ & $\begin{array}{c}\text { Anodic current } \\
\text { intensity } \\
\left(\mathrm{mA} / 10^{2}\right)\end{array}$ & $\begin{array}{c}\text { Onset potential } \\
(\mathrm{V})\end{array}$ & $\begin{array}{c}\text { Anodic current } \\
\text { intensity } \\
\left(\mathrm{mA} / 10^{2}\right)\end{array}$ & $\begin{array}{c}\text { Onset potential, } \\
x_{1}(\mathrm{~V})\end{array}$ & $\begin{array}{c}\text { Cathodic current } \\
\text { intensity } \\
\left(\mathrm{mA} / 10^{2}\right)\end{array}$ \\
\hline PdPtPt/Au-CNT & 0.30 & 140 & 0.38 & 245 & 235 & 0.10 \\
PtPdPd/Au-CNT & 0.38 & 70 & 0.41 & 265 & 0.01 & 420 \\
PtPdPt/Au-CNT & 0.30 & 120 & 0.40 & 0.10 & 320 \\
\hline
\end{tabular}

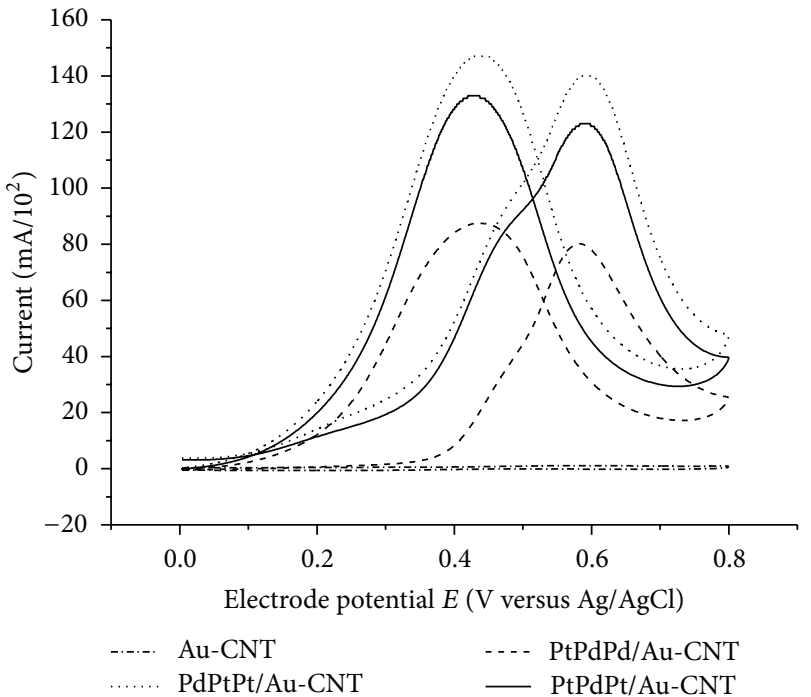

FIGURE 2: Cyclic voltammograms recorded in $2 \mathrm{MCH}_{3} \mathrm{OH}+$ $1 \mathrm{M} \mathrm{H}_{2} \mathrm{SO}_{4}$ solution at Au-CNT, PdPtPt/Au-CNT, PtPdPd/Au-CNT, and $\mathrm{PtPdPt} / \mathrm{Au}-\mathrm{CNT}$ in the potential range 0.00 to $0.80 \mathrm{~V}$ at a scan rate $0.05 \mathrm{~V} \cdot \mathrm{s}^{-1}$.

the oxide potentials of those catalysts are at $0.52,0.62$, and $0.52 \mathrm{~V}$, respectively. Oxide formation of $\mathrm{PtPdPd} / \mathrm{Au}-$ CNT appears at higher potential as high number of $\mathrm{Pd}$ on the catalyst electrode. The hydrogen desorption peaks also imply electrochemically active surface area. It can be noticed that the order of deposited metal species on Au-CNT support has a different stoichiometry for hydrogen adsorption/desorption. Moreover, the current intensities associated with the reversible hydrogen adsorption/desorption region decrease to a considerable amount depending on incorporation of $\mathrm{Pd}$ in $\mathrm{Pt}$ surface matrix with lowering the charge densities in hydrogen region.

Figure 2 shows cyclic voltammograms of methanol oxidation on $\mathrm{Au}-\mathrm{CNT}$, PdPtPt/Au-CNT, PtPdPd/Au-CNT, and $\mathrm{PtPdPt} / \mathrm{Au}-\mathrm{CNT}$ in $2 \mathrm{M} \mathrm{CH}_{3} \mathrm{OH}$ in $1 \mathrm{M} \mathrm{H}_{2} \mathrm{SO}_{4}$ in potential range of $0.00-0.80 \mathrm{~V}$ versus $\mathrm{Ag} / \mathrm{AgCl}$ at a scan rate of $0.05 \mathrm{~V} \cdot \mathrm{s}^{-1}$. The onset potential and current density of $\mathrm{Au}-\mathrm{CNT}$ are hardly determined while the current intensities obtained at $\mathrm{PdPtPt} / \mathrm{Au}-\mathrm{CNT}$, PtPdPd/Au-CNT, and $\mathrm{PtPdPt} / \mathrm{Au}-\mathrm{CNT}$ electrodes are incredibly high. Onset potentials and current intensities of the catalyst electrodes for methanol oxidation are shown in Table 1. Interestingly, the

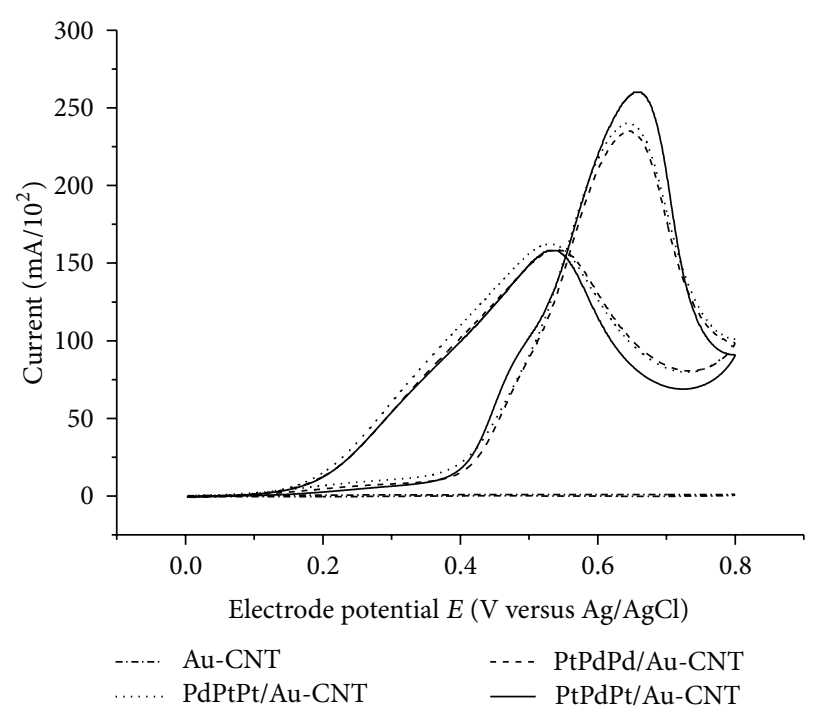

FIGURE 3: Cyclic voltammograms recorded in $2 \mathrm{M} \mathrm{CH}_{3} \mathrm{CH}_{2} \mathrm{OH}+$ $1 \mathrm{M} \mathrm{H}_{2} \mathrm{SO}_{4}$ solution at Au-CNT, PdPtPt/Au-CNT, PtPdPd/Au-CNT, and $\mathrm{PtPdPt} / \mathrm{Au}-\mathrm{CNT}$ in the potential range 0.00 to $0.80 \mathrm{~V}$ at a scan rate $0.05 \mathrm{~V} \cdot \mathrm{s}^{-1}$

onset potential for methanol oxidation shifts to less anodic potentials with increase in Pt depositon number. PdPtPt/AuCNT shows highest anodic methanol oxidation with least onset potential compared with the others.

Cyclic voltammograms of ethanol electrooxidation of those catalysts were measured in $2 \mathrm{M} \mathrm{CH}_{3} \mathrm{CH}_{2} \mathrm{OH}$ in $1 \mathrm{M} \mathrm{H}_{2} \mathrm{SO}_{4}$ solution shown in Figure 3. The voltammogram of $\mathrm{Au}-\mathrm{CNT}$ shows no ethanoic oxidation peak. Voltammograms of the catalysts show a characteristic peak with oxidation peaks in the anodic scan and second oxidation peaks in the cathodic scan. The peaks of PdPtPt/Au-CNT, PtPdPd/Au$\mathrm{CNT}$, and $\mathrm{PtPdPt} / \mathrm{Au}-\mathrm{CNT}$ are ca. $0.65 \mathrm{~V}$ in foreword scan attributed to ethanol oxidation. The peaks at ca. $0.52 \mathrm{~V}$ with current intensity ca. $1.50 \mathrm{~mA}$ in the backward scan of those catalysts are related with the reaction of the electrode giving peak to oxidation of unreacted ethanol and absorbed intermediates. With high current density and low onset potential, $\mathrm{PtPdPt} / \mathrm{Au}-\mathrm{CNT}$ illustrates high ethanol oxidation enhancements.

Three reasons of using Pt-M alloy metal to achieve oxidations of methanol and ethanol, bifunctional oxidation mechanism, alloy electronic interaction, and leaching out 


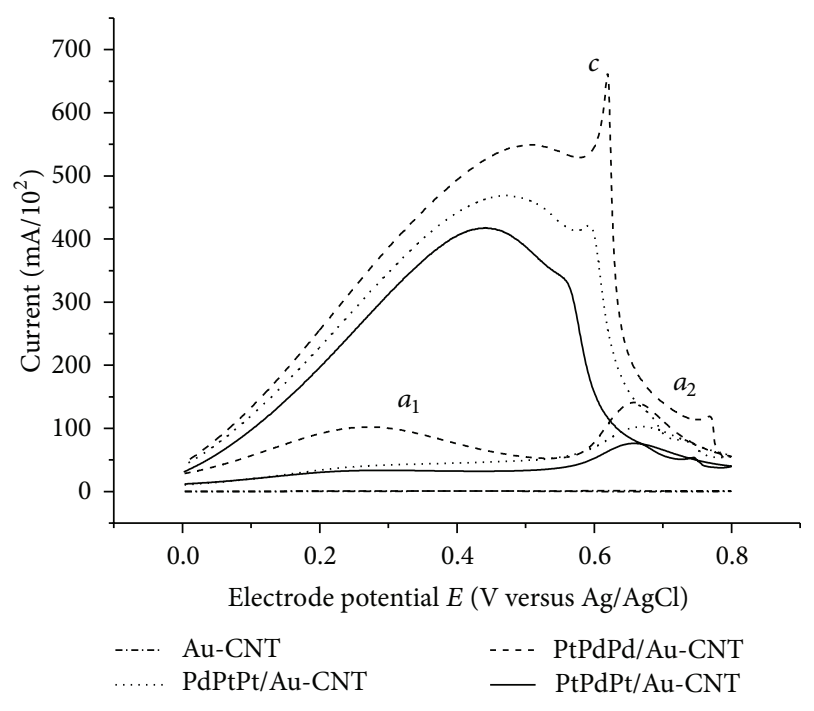

FIgURE 4: Cyclic voltammograms recorded in $2 \mathrm{MHCOOH}+$ $1 \mathrm{M} \mathrm{H}_{2} \mathrm{SO}_{4}$ solution at Au-CNT, PdPtPt/Au-CNT, PtPdPd/Au-CNT, and $\mathrm{PtPdPt} / \mathrm{Au}-\mathrm{CNT}$ in the potential range 0.00 to $0.80 \mathrm{~V}$ at a scan rate $0.05 \mathrm{~V} \cdot \mathrm{s}^{-1}$.

effect, were reported. It resulted in an increase of electrochemical active surface area $[23,24]$. Electronic effect of added metal as the alloying metal modifies the electronic structure of $\mathrm{Pt}$ valence band and weakens $\mathrm{CO}_{\mathrm{ad}}$ adsorption. This alloys $\mathrm{CO}$ adsorbed species is removed incredibly easily. Pt can adsorb alcohol molecules on its surface while the 2nd metal provides active surface oxides to oxidize adsorbed alcohols at low potential according to the following equations:

$$
\begin{gathered}
\mathrm{CO}-\mathrm{Pd}+\mathrm{OH}-\mathrm{Pd} \longrightarrow 2 \mathrm{Pd}+\mathrm{CO}_{2}+\mathrm{H}^{+}+\mathrm{e}^{-} \\
\mathrm{CO}-\mathrm{Pt}^{*}+\mathrm{OH}-\mathrm{Pd} \longrightarrow \mathrm{Pt}^{*}+\mathrm{Pd}+\mathrm{CO}_{2}+\mathrm{H}^{+}+\mathrm{e}^{-} \\
\mathrm{CO}-\mathrm{Pt} \longrightarrow \mathrm{CO}-\mathrm{Pt}^{*} \\
\mathrm{Pd}+\mathrm{H}_{2} \mathrm{O} \longrightarrow \mathrm{Pd}-\mathrm{OH}+\mathrm{H}^{+}+\mathrm{e}^{-}
\end{gathered}
$$

Please note that $\mathrm{Pt}^{*}$ is active Pt on catalyst surface.

For formic acid oxidation in Figure 4, two oxidation peaks (marked as $a_{1}$ and $a_{2}$ ) during the forward scanning and one oxidation peak (marked as $c$ ) during backward scan were obtained. It shows that the electrooxidation of formic acid would follow a previous work $[7,8,10]$. This can explain that electrooxidation of $\mathrm{HCOOH}$ on Pt-based catalysts proceeds through a dual path mechanism which is composed of direct dehydrogenation and indirect dehydrogenation pathways. Peak $a_{1}$ is attributed to the oxidation of adsorbed formate in direct pathway on the catalyst active sites. Peaks $a_{2}$ and $c$ are composed of the continuous oxidation of intermediate and adsorbed formate on CO free-Pt active sites. The anodic and cathodic current peaks and onset potentials of PdPtPt/Au$\mathrm{CNT}, \mathrm{PtPdPd} / \mathrm{Au}-\mathrm{CNT}$, and $\mathrm{PtPdPt} / \mathrm{Au}-\mathrm{CNT}$ electrodes are on Table 1. The mechanism of formic acid oxidation on the catalyst electrodes is as follows:

$$
\mathrm{HCOOH} \longrightarrow \mathrm{CO}^{*}+\mathrm{H}_{2} \mathrm{O}
$$

$$
\begin{gathered}
\mathrm{CO}^{*}+\mathrm{Pt} \longrightarrow \mathrm{Pt}-\mathrm{CO}^{*} \\
\mathrm{Pd}+\mathrm{H}_{2} \mathrm{O} \longrightarrow \mathrm{Pd}-\mathrm{OH}+\mathrm{H}^{+}+\mathrm{e}^{-} \\
\mathrm{Pd}-\mathrm{OH}+\mathrm{Pt}-\mathrm{CO}^{*} \longrightarrow \mathrm{Pd}+\mathrm{Pt}+\mathrm{CO}_{2}+\mathrm{H}^{+}+\mathrm{e}^{-} \\
\text {Overall reaction } \mathrm{HCOOH} \longrightarrow \mathrm{CO}_{2}+2 \mathrm{H}^{+}+2 \mathrm{e}^{-}
\end{gathered}
$$

As depicted in Figure 4, the PtPdPd/Au-CNT electrode exhibits much higher $\mathrm{HCOOH}$ oxidation current intensity than the others. This indicates that the incorporation of $\mathrm{Au}$ nanoparticles on CNT with the deposited Pt and Pd species greatly enhanced the reaction. The onset potential of the oxidation at the $\mathrm{PtPdPd} / \mathrm{Au}-\mathrm{CNT}$ electrode is rather low at ca. $0.00 \mathrm{~V}$ which shifts negatively compared with the others. The electrooxidation of $\mathrm{HCOOH}$ taking place at lower potential and onset potential shifting negatively reveals that the PtPdPd/Au-CNT electrode performed such a high catalytic activity. Pt-Pd structures are able to promote the electrochemical conversion of $\mathrm{CO}$ removing $\mathrm{CO}_{\text {ads }}$ surface poisons with increasing $\mathrm{Pd}$ content.

Figure 5 shows representative TEM topographic images of Au-CNT, Pt, and Pd deposited Au-CNT nanoparticle (PtPdPd/Au-CNT). The distribution of the particles is rather well dispersed with nanoparticles averaging from 5-10 nm on the CNT support. Chemical composition analysis by EDX (not shown here) indicates the presence of Pt and Pd on the $\mathrm{Au}-\mathrm{CNT}$ support.

Chemical composition analysis by using EDX indicates the presence of $\mathrm{Pt}, \mathrm{Pd}$, and $\mathrm{Au}$ on the prepared catalysts (Figure 6). However, those 3 catalysts have different amount of $\mathrm{Pt}, \mathrm{Pt}$, and $\mathrm{Au}$. An evidence of $\mathrm{Cu}$ content in the EDX spectra is attributed to $\mathrm{Cu}$ grid which is generally used for sample preparation of EDX analysis.

\section{Conclusion}

In this study, preparation of Pt and Pd sequentially electrodeposited Au metal nanoparticles loaded carbon nanotube (Au-CNT) was performed for the electrocatalytic study of methanol, ethanol, and formic acid oxidations. Cyclic voltammograms of catalysts, $\mathrm{PdPtPt} / \mathrm{Au}-\mathrm{CNT}, \mathrm{PtPdPd} / \mathrm{Au}-$ $\mathrm{CNT}$, and PtPdPt/Au-CNT catalysts, showed hydrogen adsorption/desorption reactions. The hydrogen desorption peaks imply electrochemically active surface area indicating that order of metal species deposition on Au-CNT support has a different stoichiometry for the reactions. Incorporation of $\mathrm{Pd}$ and $\mathrm{Pt}$ in $\mathrm{Au}-\mathrm{CNT}$ matrix would be able to alternate the current intensities for the different catalytic reactions. It can be concluded that the PtPdPt/Au-CNT catalyst is good at methanol oxidation, and the $\mathrm{PtPdPt} / \mathrm{Au}-\mathrm{CNT}$ enhances ethanol oxidation well while the $\mathrm{PtPdPd} / \mathrm{Au}-\mathrm{CNT}$ effectively catalyzes formic acid oxidation.

\section{Conflict of Interests}

The authors declare that there is no conflict of interests regarding to publication of this paper. 


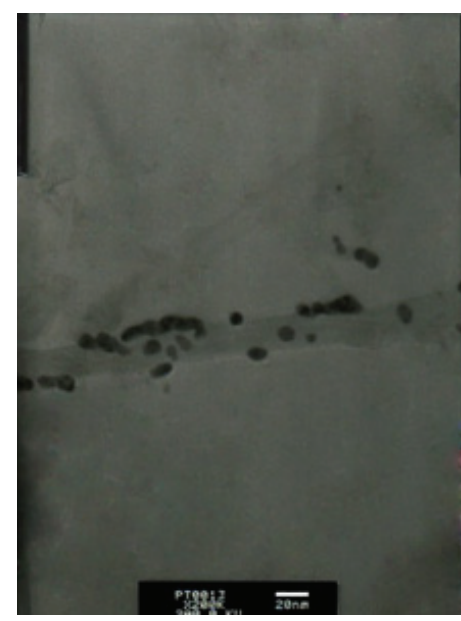

(a)

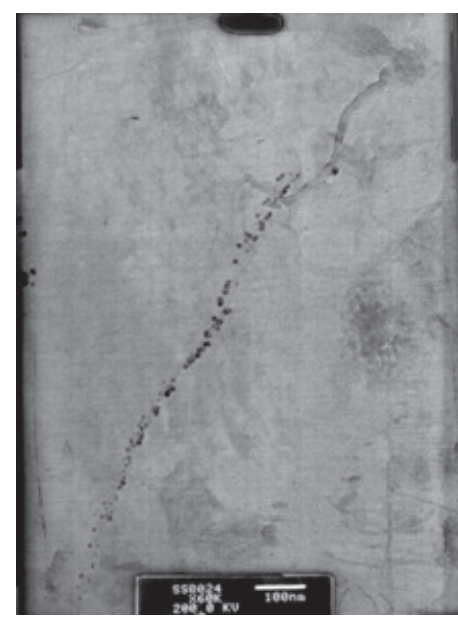

(b)

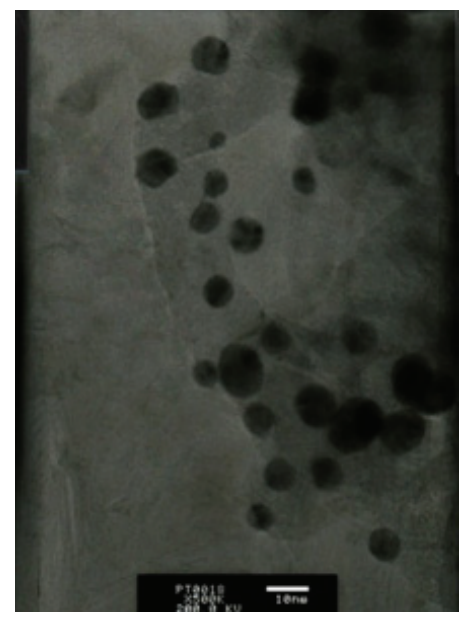

(c)

Figure 5: The selected TEM images of (a) Au-CNT, (b) Pt and Pd loaded Au-CNT with a closer TEM image (c).

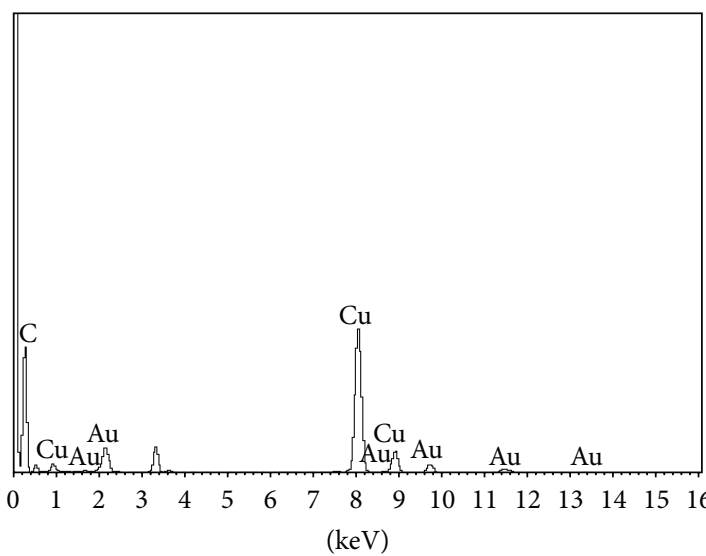

Full scale 6214 cts cursor: -0.004 (74995 cts)

(a)

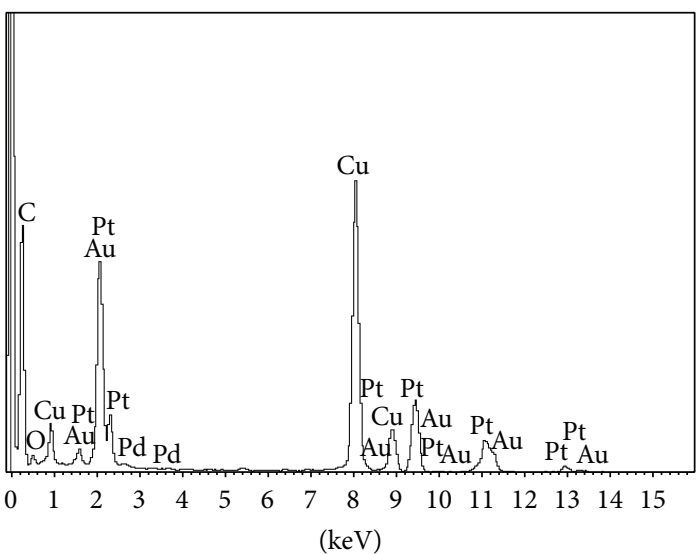

Full scale 10922 cts cursor: -0.004 (81966 cts)

(b)

Figure 6: The selected EDS spectra of (a) Au-CNT and (b) Pt and Pd loaded Au-CNT.

\section{Acknowledgments}

The authors would like to thank Faculty of Science and the National Research University Project under Thailand's Office of the Higher Education Commission and Center of Excellence for Innovation in Analytical Science and Technology and Chiang Mai University for financial support. The authors gratefully appreciated Dr. Laoungnuan Srisombat for Au nanoparticle preparation and comments.

\section{References}

[1] A. Guha, W. Lu, T. A. Zawodzinski Jr., and D. A. Schiraldi, "Surface-modified carbons as platinum catalyst support for PEM fuel cells," Carbon, vol. 45, no. 7, pp. 1506-1517, 2007.

[2] R. Parsons and T. VanderNoot, "The oxidation of small organic molecules. A survey of recent fuel cell related research," Journal of Electroanalytical Chemistry, vol. 257, no. 1-2, pp. 9-45, 1988.
[3] M. P. Hogarth and G. A. Hards, "Direct methanol fuel cells: Technological advances and further requirements," Platinum Metals Review, vol. 40, no. 4, pp. 150-159, 1996.

[4] H. Liu, C. Song, L. Zhang, J. Zhang, H. Wang, and D. P. Wilkinson, "A review of anode catalysis in the direct methanol fuel cell," Journal of Power Sources, vol. 155, no. 2, pp. 95-110, 2006.

[5] S. Wasmus and A. Küver, "Methanol oxidation and direct methanol fuel cells: a selective review," Journal of Electroanalytical Chemistry, vol. 461, no. 1-2, pp. 14-31, 1999.

[6] J. Tayal, B. Rawat, and S. Basu, "Bi-metallic and tri-metallic Pt-Sn/C, Pt-Ir/C, Pt-Ir-Sn/C catalysts for electro-oxidation of ethanol in direct ethanol fuel cell," International Journal of Hydrogen Energy, vol. 36, no. 22, pp. 14884-14897, 2011.

[7] C. Rice, S. Ha, R. I. Masel, and A. Wieckowski, "Catalysts for direct formic acid fuel cells," Journal of Power Sources, vol. 115, no. 2, pp. 229-235, 2003.

[8] S. G. Lemos, R. T. S. Oliveira, M. C. Santos, P. A. P. Nascente, L. O. S. Bulhões, and E. C. Pereira, "Electrocatalysis of methanol, 
ethanol and formic acid using a Ru/Pt metallic bilayer," Journal of Power Sources, vol. 163, no. 2, pp. 695-701, 2007.

[9] Z. He, J. Chen, D. Liu, H. Zhou, and Y. Kuang, "Electrodeposition of $\mathrm{Pt}-\mathrm{Ru}$ nanoparticles on carbon nanotubes and their electrocatalytic properties for methanol electrooxidation," Diamond and Related Materials, vol. 13, no. 10, pp. 1764-1770, 2004.

[10] P. Hong, F. Luo, S. Liao, and J. Zeng, "Effects of Pt/C, Pd/C and $\mathrm{PdPt} / \mathrm{C}$ anode catalysts on the performance and stability of air breathing direct formic acid fuel cells," International Journal of Hydrogen Energy, vol. 36, no. 14, pp. 8518-8524, 2011.

[11] A. Capon and R. Parsons, "The oxidation of formic acid at noble metal electrodes. I. Review of previous work," Journal of Electroanalytical Chemistry, vol. 44, no. 1, pp. 1-7, 1973.

[12] A. Capon and R. Parsons, "The oxidation of formic acid on noble metal electrodes II. A comparison of the behaviour of pure electrodes," Journal of Electroanalytical Chemistry, vol. 44, no. 2, pp. 239-254, 1973.

[13] F. Alcaide, G. Álvarez, P. L. Cabot, H. Grande, O. Miguel, and A. Querejeta, "Testing of carbon supported Pd-Pt electrocatalysts for methanol electrooxidation in direct methanol fuel cells," International Journal of Hydrogen Energy, vol. 36, no. 7, pp. 4432-4439, 2011.

[14] A. R. Bonesi, M. S. Moreno, W. E. Triaca, and A. M. C. Luna, "Modified catalytic materials for ethanol oxidation," International Journal of Hydrogen Energy, vol. 35, no. 11, pp. 5999-6004, 2010.

[15] Z. Liu, L. Hong, M. P. Tham, T. H. Lim, and H. Jiang, "Nanostructured $\mathrm{Pt} / \mathrm{C}$ and $\mathrm{Pd} / \mathrm{C}$ catalysts for direct formic acid fuel cells," Journal of Power Sources, vol. 161, no. 2, pp. 831-835, 2006.

[16] Y. Qiao and C. M. Li, "Nanostructured catalysts in fuel cells," Journal of Materials Chemistry, vol. 21, no. 12, pp. 4027-4036, 2011.

[17] M. Zhou, M. Chi, J. Luo, H. He, and T. Jin, "An overview of electrode materials in microbial fuel cells," Journal of Power Sources, vol. 196, no. 10, pp. 4427-4435, 2011.

[18] E. Antolini, "Carbon supports for low-temperature fuel cell catalysts," Applied Catalysis B: Environmental, vol. 88, no. 1-2, pp. 1-24, 2009.

[19] M. Łukaszewski, T. Kędra, and A. Czerwiński, "Electrochemical behavior of Pd-Pt-Au alloys," Journal of Electroanalytical Chemistry, vol. 638, pp. 123-130, 2010.

[20] D. G. Duff, A. Baiker, and P. P. Edwards, "A new hydrosol of gold clusters. 1. Formation and particle size variation," Langmuir, vol. 9, no. 9, pp. 2301-2309, 1993.

[21] I. Ávila-García, M. Plata-Torres, M. A. Domínguez-Crespo, C. Ramírez-Rodríguez, and E. M. Arce-Estrada, "Electrochemical study of PtPd, PtRu, PtRh and PtSn/C in acid media for hydrogen adsorptiondesorption reaction," Journal of Alloys and Compound, vol. 434-435, pp. 764-767, 2007.

[22] A. M. Chaparro, A. J. Martín, M. A. Folgado, B. Gallardo, and L. Daza, "Comparative analysis of the electroactive area of $\mathrm{Pt} / \mathrm{C}$ PEMFC electrodes in liquid and solid polymer contact by underpotential hydrogen adsorption/desorption," International Journal of Hydrogen Energy, vol. 34, no. 11, pp. 4838-4846, 2009.

[23] M. Soszko, M. Łukaszewski, Z. Mianowska, and A. Czerwiński, "Electrochemical characterization of the surface and methanol electrooxidation on Pt-Rh-Pd ternary alloys," Journal of Power Sources, vol. 196, no. 7, pp. 3513-3522, 2011.
[24] M. Łukaszewski and A. Czerwiński, "Electrochemical preparation and characterization of thin deposits of Pd-noble metal alloys," Thin Solid Films, vol. 518, no. 14, pp. 3680-3689, 2010. 

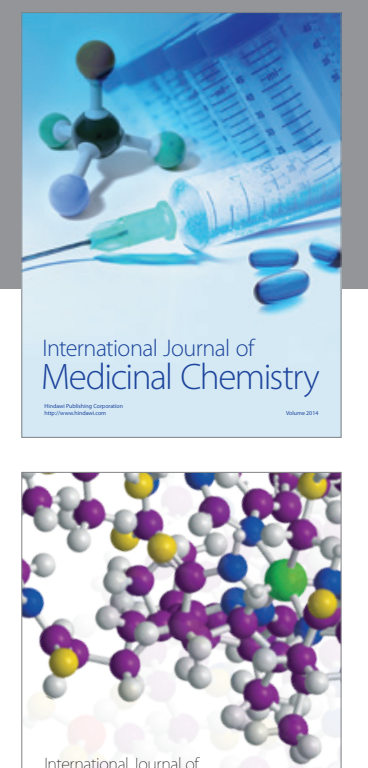

\section{Carbohydrate} Chemistry

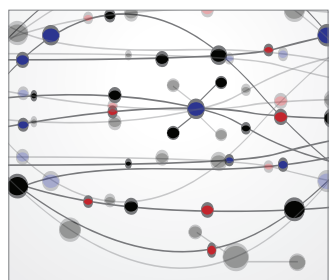

The Scientific World Journal
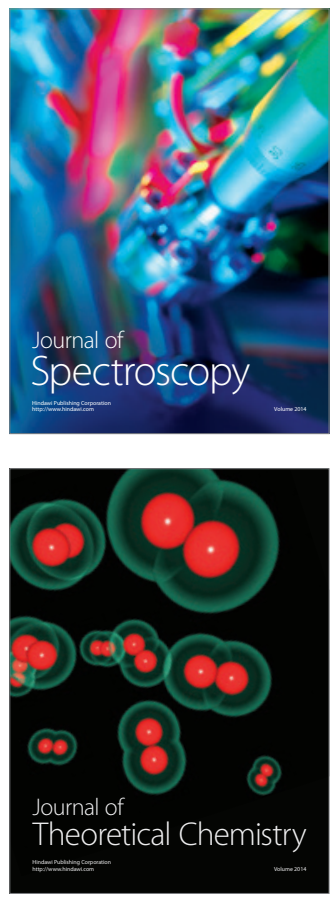
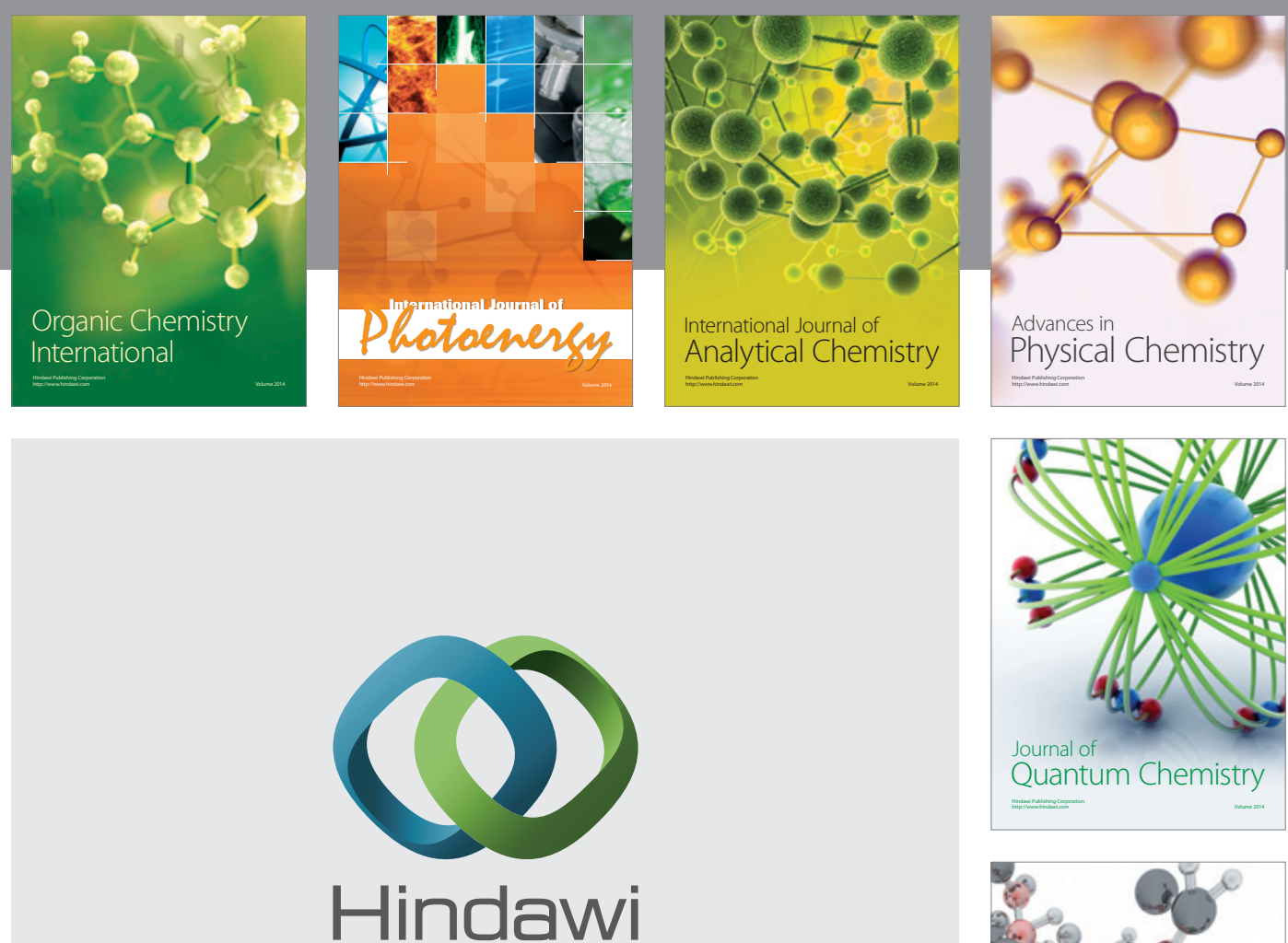

Submit your manuscripts at

http://www.hindawi.com

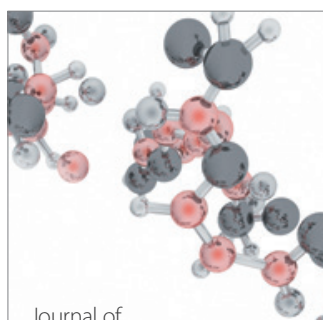

Analytical Methods

in Chemistry

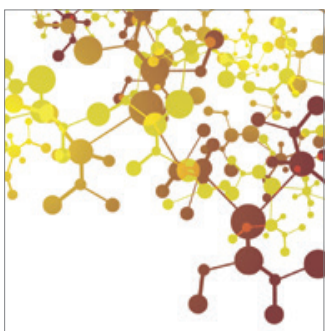

Journal of

Applied Chemistry

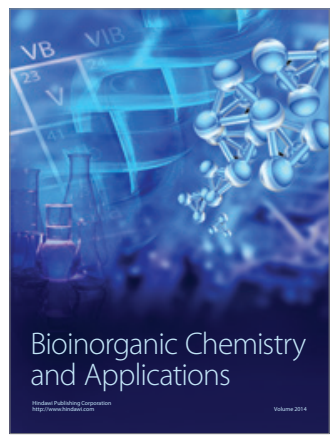

Inorganic Chemistry
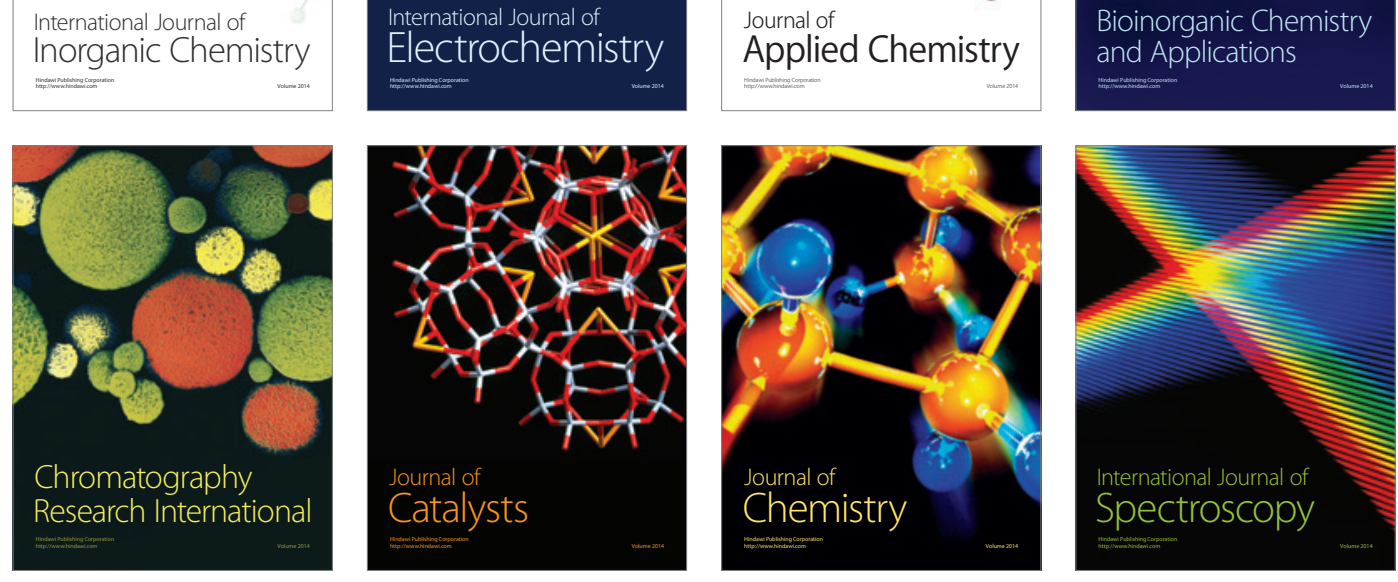